\title{
24
}

\section{REMOVING TAX BARRIERS TO CROSS-BORDER PHILANTHROPY}

\section{Lessons from Australia}

\author{
Natalie Silver
}

\section{Introduction}

Australia offers a tax deduction to encourage philanthropy, making charitable gifts less expensive for donors than they would be otherwise. Until quite recently, this tax incentive generally did not extend to cross-border philanthropy, ${ }^{1}$ notwithstanding its significance for Australian charities $^{2}$ engaged in international charitable activities. The Australian government's justification for this strict approach derived from policy concerns relating to the fiscal consequences of extending tax concessions to cross-border donations and the potential for charities operating overseas to be misused for terrorist financing and other criminal purposes (Silver, McGregor-Lowndes and Tarr, 2016, pp. 85, 109-113). As a result of this policy position, Australian donors were subject to one of the most restrictive legal regimes among OECD donor countries for the tax treatment of cross-border philanthropy.

Ironically, instead of ensuring that the benefits of these charitable tax subsidies remained in Australia, the government's restrictive approach enabled largely unregulated tax deductible cross-border giving to take place through giving intermediaries. During this period, the government's insufficient oversight and monitoring of cross-border charity and philanthropy was highlighted by the Financial Action Task Force (FATF), an intergovernmental body that promotes the implementation of measures for combating terrorist financing and money laundering in compliance with its recommendations. ${ }^{3}$ In an evaluation of Australia's domestic regulation of charities operating overseas, FATF found that Australia's supervisory framework for nonprofits was wanting, leaving them "vulnerable to misuse by terrorist organisations" (FATF and APG, 2015, p. 16).

Confronted with these regulatory shortcomings, combined with an increased number of Australian charities - almost 5,000 or 10 percent - operating and transferring funds overseas, (Australian Charities and Not-for-profits Commission, 2018, p. 8), ${ }^{4}$ the government was forced to reconsider its regulation of cross-border charity. In doing so, changes were proposed to the regulatory regime governing international charitable activities. These changes included new tools to regulate charities operating and transferring funds overseas as part of a reform package introduced to "strengthen governance arrangements, reduce administrative complexity and ensure continued trust and confidence in the sector" (O’Dwyer, 2017). 
At the same time, as a result of two judicial decisions challenging the legislative efficacy of the geographic restrictions placed around Australia's charitable tax concessions, the government decided to change policy course, culminating in a new tax ruling reflecting a more permissive approach to the tax treatment of cross-border donations (Australian Taxation Office, 2019). While the government did not provide a rationale for this policy shift, its new approach represented a change in the longstanding justification for the provision of a tax deduction for charitable gifts. In Australia, the gift deduction is characterised as a government subsidy to promote charitable activities having a public benefit (Krever, 1991, pp. 1, 5). The subsidy was justified in that it supported the domestic charitable sector provide public goods that would otherwise need to be provided by the fiscal state (Krever, 1991, p. 5; Stewart, 2014, pp. 251-252). This traditional rationale corresponds to a narrow conception of public benefit in the tax law, confining it to the fiscal state.

With a less restrictive approach to the tax treatment of cross-border donations, a more geographically expansive conception of public benefit is possible that recognises the growth in Australian cross-border charitable activities. Indeed, an Australian inquiry into the definition of charities found that "public benefit is a universal concept and cannot be contained within the boundaries of any country" (Sheppard, Fitzgerald and Gonski, 2001, p. 257). Under this pluralist rationale, the gift deduction can be justified as supporting the decentralised provision of public goods through a diverse charitable sector wherever that may be (Reich, 2011, pp. 187-190; Stewart, 2014, pp. 251-252). As a result, the public benefitting from the gift deduction can be justified as extending beyond Australia's borders to the wider global community.

This chapter examines the removal - albeit incomplete - of some of Australia's tax barriers to cross-border philanthropy. Part II focuses on the evolution of the legislative architecture governing Australian cross-border philanthropy and identifies important changes to the regulatory regime that accompanied these developments. Part III employs the traditional tax policy criteria of efficiency, equity and simplicity to evaluate the Australian's government's shift to a less restrictive approach to the tax treatment of international giving. Part IV concludes by considering how the Australian experience can inform other governments seeking to reform their own tax and regulatory regimes affecting cross-border philanthropy.

\section{Legislative architecture governing cross-border philanthropy}

Australia provides a deduction to its taxpayers as an incentive to encourage philanthropic giving. To be eligible to receive tax-deductible donations, ${ }^{5}$ an Australian organisation must obtain deductible gift recipient (DGR) status and be registered with the Australian Charities and Not-for-profits Commission, Australia's national charity regulator [Australian Charities and Not-for-profits Commission Act 2012 (Cth) s 10-5]. Most DGRs are charities, although less than 40 percent of charities are DGRs (Australian Charities and Not-for-profits Commission, 2018, p. 27). ${ }^{6}$ Charities are defined in s 5 of the Charities Act 2013 (Cth) as not-for-profit organisations established for charitable purposes that are for the public benefit. The concept of public benefit is central to the legal definition of charity, derived from the seminal English case, Commissioners for Special Purposes of Income Tax v Pemsel ([1891] AC 531 (Lord Macnaghten)). The charitable purposes enumerated in s 12 of the Charities Act 2013 (Cth) are reflected in the broad categories of deductible gifts contained in the income tax legislation, each of which contains "special conditions" (ITAA 1997, div 30).

One of the special conditions that must be met to achieve DGR status is that an organisation must be "in Australia" (ITAA 1997, s 30-15). However, the tax legislation does not provide a definition of "in Australia" for the purposes of this residency requirement. Instead, the 
Australian Tax Office, which is responsible for administering and enforcing tax law for charities and other not-for-profits, has issued public tax rulings to explain the meaning of the "in Australia" residency requirement for DGRs.

\section{A longstanding restrictive approach to the tax treatment of cross-border donations}

For more than 50 years, the Australian Tax Office interpreted the "in Australia" residency requirement for DGRs strictly. The policy imperatives underlying this restrictive approach to the tax treatment of cross border donations were to protect the national tax base by ensuring that publicly-funded tax concessions are used for the broad benefit of the Australian community and to prevent non-profit organisations being used for tax abuse purposes of money laundering, offshore avoidance arrangements and terrorist financing [Explanatory Memorandum, Tax Laws Amendment (Special Conditions for Not-for-profit Concessions) Bill 2012 (Cth), pp. 5-12; Explanatory Materials, Exposure Draft: Tax Laws Amendment (2014 Measures No \#) Bill 2014 (Cth), pp. 5-12].

The Australian Tax Office's strict interpretation of the "in Australia" residency requirement for DGRs was set out in a public tax ruling for a common sub-type of charity in Australia known as public benevolent institutions (Australian Taxation Office, 2003, para 129). Public benevolent institutions provide direct services to those in need of benevolent relief or raise funds for the purpose of providing benevolent relief [Australian Charities and Not-for-profits Commission Act 2012 (Cth) s 25-5(5) column 2, item 6]. They encompass organisations whose purpose it is to relieve poverty, sickness, suffering or disability. The Australian Tax Office's “in Australia" ruling for public benevolent institutions stated that for a public benevolent institution to be endorsed as a DGR it was required to be "in Australia", such that it "must be established, controlled, maintained and operated in Australia and its benevolent purposes must be in Australia” (Australian Taxation Office, 2003, para 128). The tax ruling further clarified that because the purpose of a public benevolent institution was to provide direct relief to persons in need, "this will mean that relief will be provided to people located in Australia" (Australian Taxation Office, 2003, para 129).

In practical terms, the result of this "in Australia" tax ruling was that donations by Australian taxpayers made directly to a charity outside Australia were never tax deductible. It also meant that donations made to an Australian DGR to use the gift for its own programs outside Australia were also not tax deductible, unless such activities were relatively minor or incidental to the organisation's Australian operations (Australian Taxation Office, 2003, para 130). Importantly, some limited exceptions to the "in Australia" residency requirement for DGRs are contained in the tax legislation. An organisation can obtain DGR status and use tax deductible donations for its activities outside Australia if it establishes an overseas aid fund undertaking development and humanitarian activities, a developed country disaster relief fund or a public fund on the Register of Environmental Organisations or if it is specifically listed by name in the tax legislation under the category of international affairs (ITAA 1997 ss 30-55, 30-80, 30-85). However, due to the high entry barriers resulting from initial heavy vetting, relatively few organisations have obtained DGR status through one of these purposefully limited exceptions (Silver, McGregorLowndes and Tarr, 2016, pp. 96-103).

Australia's restrictive approach to the provision of tax incentives for cross-border philanthropy was significant when compared to other OECD donor countries. A comparative analysis of the tax laws and policies governing cross-border philanthropy in the functionally comparable jurisdictions of Belgium, Canada, France, Germany, Japan, Luxembourg, the 
Netherlands, Spain, the United Kingdom and the United States revealed that Australia's use of domestic tax policy to place geographic barriers around charitable tax relief for donors located it at the most restrictive end of the spectrum of approaches to the tax treatment of cross-border donations. At the other, most permissive, end of the spectrum was The Netherlands, which applies the same tax treatment to domestic and cross-border donations by allowing the registration of eligible foreign entities as Dutch charities. Other countries at the restrictive end of the spectrum are those which, like Australia, have tax laws with "in country" residency requirements, including Canada, Japan and the United States. However, because these jurisdictions generally permit a tax deduction for cross-border donations made indirectly through domestic charities, they were classified as less restrictive than Australia (Silver and Buijze, 2020, pp. 119-122).

In addition to limiting the ability of Australian donors seeking to obtain a tax deduction for donations directed overseas, the Australian Tax Office's longstanding interpretation of the "in Australia" residency requirement for DGRs had other unintended consequences. With few options for engaging in tax-effective overseas giving, many Australian nonprofit organisations and their donors resorted to using workarounds to channel tax-deductible funds abroad. This was achieved by using organisations that had obtained DGR status pursuant to one of the limited exceptions to the "in Australia" residency requirement as giving intermediaries (Australian Bureau of Statistics, 2015, table 10.1). ${ }^{7}$ These channelling arrangements, involving a servicing fee being paid to the intermediary DGR, ${ }^{8}$ created a workaround for organisations and their donors, enabling them to circumvent the strict "in Australia" residency requirement for DGRs in order to engage in tax-effective cross-border charitable activities (Silver, McGregor-Lowndes and Tarr, 2016, pp. 95, 103). In doing so, this fee-paying workaround compromised the government's ability to regulate cross-border charity through the tax laws. This in turn made monitoring cross-border charitable flows far more difficult and increased the risks that these funds could be used for tax abuse and terrorist financing purposes.

The Australian government's inadequate oversight and supervision of cross-border charity was exposed in a report by FATF, which assesses terrorist financing vulnerabilities and threats faced specifically by the nonprofit sector through its Recommendation 8 . This Recommendation serves as an international policy standard influencing the domestic regulation of charities operating overseas. In its evaluation report of Australia in 2015, FATF rated Australia "noncompliant" with Recommendation 8, finding that Australia had "not implemented a targeted approach nor [had] it exercised oversight in dealing with nonprofit organisations that are at risk from the threat of terrorist abuse" (FATF, 2015, p. 6).

During this period where the efficacy of the "in Australia" residency requirement for DGRs was being scrutinised internationally, the government's restrictive position on this issue was also being challenged in the Australian courts. A landmark decision of the High Court of Australia in Federal Commissioner of Taxation v Word Investments Ltd (2008) 236 CLR 204 considered the "in Australia" residency requirement for income tax exemption, which differs slightly to that for DGRs. The Court found that this requirement did not mean that charitable funds transferred through a suitably qualified charitable intermediary needed to be expended in Australia; it only imposed a requirement that the charitable intermediary incur its expenditure and pursue its objectives principally in Australia (p. 239 [73]). This decision was affirmed in Federal Commissioner of Taxation v The Hunger Project Australia (2014) 221 FCR 302, where the issue was whether Hunger Project Australia qualified as a public benevolent institution in Australia. Hunger Project Australia was part of a global network of entities whose purpose was to relieve hunger in developing countries. While Hunger Project Australia was primarily a fundraising arm for other Hunger Project entities engaged in the direct provision of hunger relief outside 
Australia, the organisation had some involvement in global and program decision-making. The Federal Court of Australia found that despite the fact that Hunger Project Australia did not itself directly give or provide relief but rather did so via its related entities, it nonetheless qualified as a public benevolent institution and was therefore eligible to apply for income tax exemption and DGR status (p. 314 [67]).

These two judicial decisions had significant implications for the Australian Tax Office's strict interpretation of the "in Australia" residency requirement for DGRs. By interpreting the "in Australia" residency requirement for income tax-exempt entities as not mandating that the ultimate purposes or beneficiaries be in Australia, these decisions suggested that, similarly, an organisation's purposes or beneficiaries may not need to be "in Australia" to qualify for DGR status.

\section{A new less restrictive approach to the tax treatment of cross-border donations}

Faced with both legal and practical challenges to its longstanding interpretation of the "in Australia" residency requirement for DGRs, in 2017, the Australian Tax Office withdrew its "in Australia" public tax ruling for public benevolent institutions (Australian Taxation Office, 2017). At the same time, the Australian Tax Office cited a statement issued by the Commissioner of the Australian Charities and Not-for-profits Commission that an organisation "is not precluded from being registered as a [public benevolent institution] subtype of charity if it has a main purpose of providing benevolent relief to people residing overseas" (2016, s 5.8). This was followed by an announcement that the Australian Tax Office would be issuing a new public tax ruling on the "in Australia" residency requirement for DGRs and income tax-exempt entities (Australian Taxation Office, 2018).

The new public tax ruling was issued in December 2019. This tax ruling is not limited to public benevolent institutions. Instead it is concerned with DGRs and income tax-exempt entities more broadly. The tax ruling states that a DGR satisfies the "in Australia" residency requirement for DGRs in the tax legislation so long as it is "established or legally recognised in Australia, and makes operational or strategic decisions mainly in Australia" (Australian Taxation Office, 2019, para 7). Importantly, there is no requirement that the organisation's purposes or beneficiaries be in Australia. The practical result of this new tax ruling is that while donations by Australian taxpayers made directly to a charity outside Australia are still not tax deductible, donations made to a qualified Australian DGR to use the gift for its own programs and those of its eligible related entities outside Australia are now tax deductible, provided that organisation's operational or strategic decisions occur "mainly in Australia" (Australian Taxation Office, 2019, paras 19, 35). ${ }^{9}$ With this less restrictive approach to the provision of tax incentives for international philanthropy, Australia's location on the tax treatment of cross-border giving spectrum has shifted further towards the permissive end of the spectrum, albeit far from The Netherlands' equivalency ideal.

In the intervening years, while the charitable sector in Australia awaited the new public tax ruling, Australian organisations and their donors took advantage of the legal vacuum that existed by establishing public benevolent institutions with DGR status for the purpose of sending funds and engaging in charitable activities outside Australia. ${ }^{10}$ By the end of 2017, approximately 10 percent of all charities in Australia reported operating overseas (Australian Charities and Not-for-profits Commission, 2018, p. 8), ${ }^{11}$ a significant increase from approximately 6 percent of all charities in 2013 (Cortis et al., 2016, p. 11). More than three-quarters of these charities reported transferring funds overseas (Powell et al., 2017, p. 11). The rise in Australian charities 
operating and sending funds outside Australia signified the need for increased regulatory oversight and monitoring of these organisations.

\section{New regulatory tools governing cross-border charitable activities}

The Australian government responded to the criticism it had received from FATF in 2015 by conducting a national risk assessment into the charitable sector (AUSTRAC, 2017). The risk assessment found that while there were few proven instances of money laundering and terrorism financing - consistent with other assessments (AUSTRAC, 2014; AUSTRAC, 2016) there remained a "medium" risk level of organisations being misused for such purposes (AUSTRAC and Australian Charities and Not-for-profits Commission, 2017, p. 39). Recommendations from the risk assessment focused on measures to strengthen the oversight and monitoring of international charitable activities. FATF conducted a follow-up report in 2018 analysing Australia's progress in implementing new requirements relating to recommendation 8 (FATF, 2018). In the period between its two reports on Australia, FATF amended Recommendation 8 , emphasising the need for governments to adopt "effective and proportionate measures commensurate to the risks identified through a risk-based approach that respects countries' obligations under the Charter of the United Nations and international human rights law" (FATF, 2016, pp. 54-55). ${ }^{12}$ FATF's follow-up report concluded that Australia was "largely compliant" with the revised Recommendation 8, citing the comprehensive risk assessment Australia had taken of its nonprofit sector. However, the report also noted "concerns that some smaller charities, which are identified as potentially higher-risk, are not subject to adequate monitoring" (FATF, 2018, p. 6), signalling that changes to Australia's regulatory framework governing these organisations were required.

To ensure compliance with its international obligations under FATF Recommendation 8 and to address the concomitant rise in Australian charities operating overseas, the Australian government undertook an assessment of the regulatory regime governing cross-border charity, resulting in a DGR reform package (The Treasury, 2018). The Australian Charities and Not-for-profits Commission has had a range of regulatory tools at its disposal, provided for in the Australian Charities and Not-for-profits Commission Act 2012 (Cth), including registration and reporting requirements, governance standards, penalties for non-compliance and revocation of charitable status. However, the DGR reform package introduced new tools specifically for regulating the sub-sector of charities with DGR status that operated outside Australia.

The most significant new reform measure introduced to strengthen the oversight and monitoring of cross-border charitable activities was the issuance of external conduct standards, which came into effect in 2019 [Australian Charities and Not-for-profits Commission Amendment (2018 Measures No. 2) Regulations 2018]. While Australia's charity legislation had made provision for external conduct standards since the inception of the Australian Charities and Not-forprofits Commission in 2012, these standards were only developed and implemented as part of the DGR reform package in 2018.

The regulations adopted to implement the external conduct standards stated that the objectives are

to provide greater confidence that funds sent, and services provided, outside Australia are reaching legitimate beneficiaries and are being used for legitimate purposes ... and to prevent a registered entity from being misused by a criminal organization. 
Pursuant to the regulations, the external conduct standards apply to a registered entity if it operates outside Australia or works with third parties that operate outside Australia, unless its overseas activities are "merely incidental" to its operations and pursuit of its purposes in Australia (s 50.4). There are four external conduct standards, which require charities engaging in cross-border charitable activities to appropriately manage their overseas activities and control of resources (s. 50.20), conduct an annual review of their overseas activities on a country-bycountry basis (s 50.25), ensure they have appropriate anti-fraud and anti-corruption measures in place (s 50.30) and protect vulnerable individuals outside Australia from exploitation or abuse (s 50.35).

These external conduct standards combined with the new "in Australia" tax ruling represent an opportunity for the Australian government to provide the necessary regulatory oversight and monitoring of cross-border charity to facilitate legitimate cross-border charitable flows. The next section analyses Australia's new approach to cross-border charitable activities utilising normative tax policy considerations that inform policy-making across jurisdictions.

\section{Tax policy analysis}

A review of the Australian tax system found it to be generally "accepted that a well-designed tax system will meet its revenue raising objective, while balancing the core principles of equity, efficiency and simplicity" (The Treasury, 2015, p. 14). Reform of domestic tax laws are frequently shaped by these traditional tax policy concerns of equity, economic efficiency and simplicity of administration and compliance (Graetz, 1995, p. 609; O'Connell, 2008, p. 19). With a new interpretation by the Australian Tax Office of the "in Australia" residency requirement for DGRs, it is worthwhile considering how the current legislative architecture for the tax treatment of cross-border giving in Australia holds up against these tax policy considerations. ${ }^{13}$ The following tax policy analysis evaluates the benefits of the gift deduction as it applies to crossborder donations against the potential inequities, inefficiencies and complexities the deduction might produce.

\section{Equity}

There are two conceptions of equity to be considered when evaluating a national tax system: horizontal equity and vertical equity. The former involves the idea that "people with equal ability to pay taxes pay equal amounts of tax", while the latter is concerned that "those with greater ability to pay, pay more" (Graetz, 1995, p. 610). For domestic donations, the gift deduction is generally seen as satisfying horizontal equity because taxpayers with a similar capacity to pay are treated the same. For example, in Australia, taxpayers in the highest tax bracket of 49 percent each pay 51 cents after tax for each dollar donated, while taxpayers in the lowest 19 percent bracket each pay 81 cents. However, the gift deduction has been criticised on vertical equity grounds for decreasing the equity of the tax system. This is because progressive rates of personal income tax result in the deduction having greater value for those taxpayers on higher incomes (Australia's Future Tax System Review Panel, 2010, p. 726). The result is an "upside down effect" whereby the wealthier the donor, the less a charitable gift costs (Krever, 1991, pp. 219-220; Gergen, 1988, p. 1405). This inequity is compounded given that higher-income taxpayers are allocated more of the tax subsidy, as they have the resources to make larger donations compared to lower-income taxpayers. Vertical inequity can therefore be seen as a "critical flaw" of the gift deduction that renders it "at best, 'undemocratic' and at worst unacceptably elitist" (Krever, 1991, p. 21). 
Applying these concepts of horizontal and vertical equity to cross-border donations requires a further level of analysis. Horizontal equity is arguably not achieved if the gift deduction is only available for donors in the same tax bracket who choose to give domestically but not for those whose donations are directed internationally. Instead, equal tax treatment for domestic and cross-border donations would be required. While Australia's more permissive approach to the tax treatment of cross-border donations does not meet this horizontal equity ideal in that gifts made directly to foreign charities are still not tax deductible, it does create greater horizontal equity than existed under the government's more restrictive approach. This is because the Australian Tax Office's new interpretation of the "in Australia" residency requirement for DGRs allows a deduction for Australian taxpayers in the same tax bracket for gifts made to qualified Australian charities that operate abroad.

An additional consideration for vertical equity is whether a higher level of income has a significant effect on the likelihood of giving internationally. This would make Australia's more permissive approach to the tax treatment for cross-border donations arguably more justifiable. In Australia, income has been shown to have a negative correlation with support for foreign aid and is not statistically significant for private donations to aid organisations. Instead, tertiary education is the strongest positive socio-economic determinant of both support for foreign aid and private donations to aid organisations (Wood, Humphrey Cifuentes and Pryke, 2014). This is consistent with studies in other jurisdictions (Casale and Baumann, 2015, p. 117; Micklewright and Schnepf, 2009, p. 335; Wiepking, 2010, p. 1081). As a result, even with a new interpretation by the Australian Tax Office of the "in Australia" residency requirement for DGRs, vertical equity issues remain.

Beyond the conceptions of horizontal equity and vertical equity which focus on a national tax system, equity can also be considered from a broader perspective that extends beyond national borders. Under this broader view, a generous tax deduction for cross-border donations may reduce global inequities given that most cross-border giving from wealthy countries is directed to developing countries (Roodman and Standley, 2006, pp. 5-6). This redistributive effect "might have especially powerful welfare effects for the world's most disadvantaged" (Pozen, 2006, p. 583). Australia's more permissive approach to the tax treatment of cross-border giving has the potential to assist in reducing global inequities as more charitable funds are redistributed from Australia to poorer countries.

\section{Efficiency}

The gift deduction is widely viewed as a government subsidy or tax expenditure, the fiscal equivalent of a direct government spending program, because it "triggers a reduction of taxable income and, as a result, a tax saving, that would not be available in a benchmark income tax system which treated charitable gifts similarly to all other gifts or uses of income" (Krever, 1991, p. 5). Because of the tax savings arising from gift deductibility, the donor does not bear the entire cost of the gift, and the government forgoes tax revenue. This raises the question of whether the gift deduction is a cost-effective way to subsidise charitable organisations. Economic (or treasury) efficiency is concerned with understanding whether the public benefit derived from the gift deduction exceeds the costs of the subsidy - specifically, whether a dollar of forgone taxes creates at least an extra dollar of charitable donations or (if not) whether the subsidy should be replaced with direct spending (Colinvaux, Galle and Steuerle, 2012, p. 8).

One measure of whether the gift deduction is efficient in encouraging donors to give to charity is to consider the price elasticity of giving. If giving is price elastic, then lowering the price of giving through tax incentives can potentially increase both the amount donated and 
the number of individuals donating (Simon, Dale and Chisolm, 2006, p. 272; Colinvaux, Galle and Steuerle, 2012, p. 9). On the other hand, if giving is price inelastic, then the tax deduction is an inefficient way to fund charitable organisations. On balance, empirical studies indicate that the price elasticity of giving has absolute value greater than one, at least among individuals with high incomes (Gergen, 1988; Peloza and Steel, 2005; Bakija and Heim, 2011; List, 2011). Indeed, high top marginal tax rates in Australia suggest that for wealthy taxpayers, the gift deduction would have a significant impact on giving (McGregor-Lowndes and Crittall, 2015, pp. 7, 61). While there have not been studies to determine the price elasticity of cross-border giving, one comparative study of charitable giving to developing countries found that individuals in countries with targeted income tax incentives give more to developing countries (Roodman and Standley, 2006, p. 35). This suggests that the gift deduction may be a cost-effective way to subsidise international charitable activities.

Whether a tax deduction for cross-border donations increases economic efficiency also depends on the wider social objectives of the deduction and the scope of the public who should benefit. The Australian government historically took a narrow view of treasury efficiency, largely confining the benefits of the deduction to the Australian public. According to this view, a generous deduction for cross-border donations would decrease treasury efficiency within Australia due to the consequences for the public purse. However, with the government's shift in policy and a new interpretation of the "in Australia" residency requirement for DGRs, a broader view of economic efficiency appears to have been adopted pursuant to which a deduction for cross-border donations is economically efficient in its cost-effective delivery of support to beneficiaries overseas. Under this broader view of treasury efficiency, it is also arguable that globally net social welfare will be increased with a more permissive approach to the tax deductibility of cross-border donations (Pozen, 2006, p. 580). Indeed, all Australians stand to benefit from cross-border gifts that fund organisations involved in the production of global public goods, such as medical breakthroughs associated with the development of vaccinations for COVID-19 or solutions for the climate change crisis. In such situations, the Australian government receives a return or benefit for the public funds expended.

\section{Simplicity}

Tax laws should be simple for taxpayers to comply with and for administrators to implement (Graetz, 1995, p. 609). Tax expenditures such as the gift deduction "can add complexity to the tax system [in that they] complicate the law and create additional choices for people" (Australia's Future Tax System Review Panel, 2010, p. 726). A recurring theme in the Australian nonprofit tax literature is criticism of the not-for-profit tax concessions for their complexity (O'Connell, 2008, pp. 19-20). For example, not only is the process for obtaining deductible gift recipient status in Australia complicated, "there are five initial categories of recipient and then a further 14 categories (different to the categories for income tax exemption) that each have a general category and a specific category for specifically listed entities" (O'Connell, 2021, p. 30). Such complexity is not surprising given that the charitable tax concessions in Australia developed by way of "ad hoc decision-making" rather than "considered policy analysis" (O'Connell, 2021, p. 36).

When applied to cross-border donations, the complexity surrounding the gift deductibility provisions generally increases. In Australia, the complex legislative architecture governing the tax treatment of cross-border donations had lacked clarity, particularly as the meaning of "in Australia" is not stated in the tax legislation and has required interpretation by the Australian Tax Office. Organisations engaging in international charitable activities and their donors 
are required to navigate the complex laws and cumbersome processes surrounding the "in Australia" residency requirement for DGRs and its exceptions to determine whether they are eligible for DGR status.

The new "in Australia" tax ruling provides some clarity for organisations operating overseas and their donors and in doing so reduces the need for complex workarounds to facilitate taxeffective cross-border giving. When regulatory reforms for cross-border charity are also taken into account, the overall result is a less complicated, more streamlined system for both taxpayers and administrators.

\section{Summary}

The Australian government's longstanding approach to the tax treatment of cross-border donations prioritised fiscal consequences over other tax policy considerations. This resulted in a reduced capacity of the traditional tax concerns to influence policymaking with respect to cross-border philanthropy. With a new, less restrictive approach, it is possible to evaluate the benefits of the gift deduction as it applies to cross-border donations against these tax considerations. A tax policy analysis reveals that while there are some costs to the public purse and vertical inequities persist, on balance, the government's more permissive approach to cross-border philanthropy better promotes economic efficiency in the broad sense as a cost-effective way to subsidise international charitable activities and ultimately contributes to a reduction in global inequities due to the redistributive effect on the global allocation of resources. This approach also has the potential to reduce the complexity associated with tax deductibility for cross-border donations by providing legislative clarity and regulatory specificity for charities operating overseas and their donors while simplifying administration for regulators.

\section{Conclusion}

A recent OECD report on taxation and philanthropy found that "[d]espite fairly widespread use of incentives for domestic philanthropy, the landscape for a more global approach to philanthropy remains fairly guarded" (2020, p. 109). For many years, the Australian government epitomised this guarded approach with its longstanding policy prohibiting tax concessions for cross-border philanthropy mitigated by special exemptions with high entry barriers. The result was that Australia, like many donor countries around the world, was faced with a legal and regulatory environment for cross-border giving where a tension existed between effective government regulation and a desire for donors to engage in tax-effective international philanthropy.

In theory, the government's strict approach limited the ability of Australian donors to get a tax deduction for cross-border donations by requiring these gifts to be made through organisations that had succeeded in obtaining DGR status under one of the very limited exceptions to the "in Australia" residency requirement. Yet in practice, instead of ensuring that the benefits of these charitable tax subsidies remained in Australia, this approach enabled largely unregulated tax deductible crossborder giving to take place through giving intermediaries. The channelling workaround used to circumvent the restrictive tax laws was costly for donors and stifled their ability to engage in tax effective cross-border giving. At the same time, it compromised the ability of the Australian authorities to appropriately monitor cross-border charitable flows, underscored by FATF's evaluation of Australia's regulation of charities operating overseas. As a result, the government was unable to provide effective regulatory supervision of cross-border philanthropy. This failed approach, recognised by the Australian courts, is a lesson for other jurisdictions in what not to do. 
Following these judicial decisions challenging the geographic restrictions placed around the charitable tax concessions, the Australian government has acknowledged the shortcomings of its overly restrictive approach to the tax treatment of cross-border donations. In doing so, it has changed policy course by issuing a new "in Australia" tax ruling for DGRs that provides greater scope for some Australian charities and their donors to engage in tax effective cross-border charitable activities. While restrictions remain in place, such that Australian "cross-border donations are not incentivized as a general principle" (OECD, 2020, pp. 109-110, Table 5.1), for those organisations that qualify for DGR status, the government's new approach alleviates the need for charities and their donors to engage in workarounds of the tax laws. Indeed, a tax policy analysis demonstrates that although the government's new approach to the tax treatment of cross-border donations is not without domestic costs, the benefits to both the Australian community and the wider global community are difficult to ignore. With the establishment of a more appropriate supervisory framework for monitoring cross-border giving, there is potential for greater transparency of cross-border charitable activities which will advance Australia's tax abuse risk profile.

The government's reduction of some of the territorial barriers around charitable tax relief for donors, combined with new tools for regulating international giving, is a first step towards reforming Australia's legal and regulatory regime governing cross-border philanthropy. The extent to which this less guarded approach achieves a more appropriate balance between ensuring adequate oversight of cross-border charitable flows while enabling Australian citizens to effectively contribute to the wider global community remains to be seen.

\section{Notes}

1 Defined as a charitable gift from a donor in one jurisdiction to a recipient in another. This term will be used throughout this chapter interchangeably with "international philanthropy" and "international giving".

2 Charities are a subset of not-for-profit organisations that meet the statutory definition of charity under the Charities Act 2013 (Cth).

3 Australia is a founding member of FATF, which was established in 1989.

4 This includes transferring funds or goods, or delivering programs, outside Australia.

5 Under the Income Tax Assessment Act 1997 (Cth), s 30-15 (ITAA 1997), Australian residents can deduct from their taxable income the value of donations of AUD $\$ 2$ or more made to a DGR.

6 Other not-for-profit organisations eligible to become DGRs include government institutions, income tax-exempt funds, and organisations with purposes that are primarily sporting or recreational in nature. The Treasury Laws Amendment (2021 Measures No. 2) Act 2021 amends the ITAA 1997 to require non-government DGRs (other than ancillary funds) to register as a charity from 14 December 2021.

7 'Grants and other payments' made by Australian non-profit organisations to 'non-resident organisations' (defined as any organisation domiciled overseas, including foreign branches and subsidiaries of Australian organisations) amounted to more than AUD $\$ 1$ billion, highlighting the widespread use of domestic nonprofits for cross-border giving, a significant component of which is likely to be intermediary giving.

8 This servicing fee was typically 7-10 percent of the amount distributed. See Letter from Philanthropy Australia to Prime Minister Tony Abbott, 21 April 2015, 1 (on file with author).

9 The location of decision making is determined on the basis of where the organisation's decisionmaking powers are mainly exercised, such that if the decision makers are located in more than one place, operational or strategic decisions would be made "mainly in Australia" provided the balance of decision-making power usually lies in Australia.

10 Data from the Australian Charities and Not-for-profits Commission's registration database as at 24 May 2017 shows that the number of public benevolent institutions operating overseas has been steadily increasing since 2013-2016 by an average of approximately 300 per year (on file with author). 
11 This includes transferring funds or goods, or delivering programs, outside Australia.

12 This change represented an acknowledgment be FATF that the non-profit sector's vulnerability to terrorist abuse may previously have been overstated given that "not all non-profit organisations are inherently high risk (and some may represent little or no risk at all)".

13 A tax policy analysis of Australia's long-standing restrictive approach to the tax treatment of crossborder donations was undertaken in Silver and Buijze (2020, pp. 136-148).

\section{References}

AUSTRAC (2014) Terrorism Financing in Australia 2014, Canberra: Commonwealth of Australia.

AUSTRAC (2016) Regional Risk Assessment on Terrorism Financing 2016: South East Asia and Australia, Canberra: Commonwealth of Australia.

AUSTRAC and Australian Charities and Not-for-profits Commission (2017) Australia's Non-Profit Organisation Sector: National Risk Assessment on Money Laundering \& Terrorism Financing, Canberra: Commonwealth of Australia.

Australian Bureau of Statistics (2015) Australian National Accounts: Non-Profit Institutions Satellite Accounts 2012-13, Catalogue No 5256, Canberra: Commonwealth of Australia <www.abs.gov.au/AusStats/ ABS@.nsf/MF/5256.0>.

Australian Charities and Not-for-profits Commission (2018) Australian Charities Report $2017<$ https:// www.acnc.gov.au/tools/reports/australian-charities-report-2017>.

Australia's Future Tax System Review Panel (2010) Australia's Future Tax System: Report to the Treasurer, Canberra: Commonwealth of Australia.

Bakija, J. and Heim, B. (2011) 'How Does Charitable Giving Respond to Incentives and Income? New Estimates from Panel Data' National Tax Journal 64(2), p. 615.

Casale, D. and Baumann, A. (2015) 'Who Gives to International Causes? A Sociodemographic Analysis of US Donors' Nonprofit and Voluntary Sector Quarterly 44(1), p. 98.

Colinvaux, R., Galle, B. and Steuerle, E. (2012) Evaluating the Charitable Deduction and Proposed Reforms, Washington: The Urban Institute.

Cortis, N. et al. (2016) Australian Charities Involved Overseas 2014, Sydney: University of New South Wales.

FATF (2016) International Standards on Combatting Money Laundering and the Financing of Terrorism \& Proliferation: The FATF Recommendations, Paris: OECD/FATF.

FATF (2018) Anti-Money Laundering and Counter-Terrorist Financing Measures - Australia: 3rd Enhanced Follow-Up Report \& Technical Compliance Re-Rating, Paris: FATF < http:www.fatf-gafi.org/publications/ mutualevaluations/documents/fur-australia-2018.html>.

FATF and APG (2015) Anti-Money Laundering and Counter-Terrorist Financing Measures - Australia, Fourth Round Mutual Evaluation Report, FATF, Paris and APG, Sydney <www.fatf-gafi.org/topics/mutualevaluations/documents/mer-australia-2015.html>.

Gergen, M. (1988) 'The Case for a Charitable Contributions Deduction' Virginia Law Review 74(8), p. 1391.

Graetz, M. (1995) 'Paint-by-Numbers Tax Lawmaking' Columbia Law Review 95(3), p. 609.

Krever, R. (1991) 'Tax Deductions for Charitable Donations: A Tax Expenditure Analysis' in Krever, R. and Kewley, G. (eds.), Charities and Philanthropic Institutions: Reforming the Tax Subsidy and Regulatory Regimes, Sydney: Australian Tax Research Foundation, pp. 1-28.

List, J. (2011) 'The Market for Charitable Giving' Journal of Economic Perspectives 25(2), p. 157.

McGregor-Lowndes, M. and Crittall, M. (2015) An Examination of Tax Deductible Donations Made by Individual Australian Taxpayers in 2012-13, Australian Centre for Philanthropy and Nonprofit Studies, Queensland University of Technology Working Paper No. 66.

Micklewright, J. and Schnepf, S. (2009) 'Who Gives Charitable Donations for Overseas Development?' Journal of Social Policy 38(2), p. 317.

O'Connell, A. (2008) 'The Tax Position of Charities in Australia - Why Does It Have to Be So Complicated?' Australian Tax Review 37(1), p. 17.

O'Connell, A. (2021) Taxation of Charities and Not-for-Profits, Australia: LexisNexis.

O'Dwyer, K. (2017) Reforming Administration of Deductible Gift Recipients, Media Release, <http://kmo. ministers.treasury.gov.au/media-release/114-2017/>.

OECD (2020) Taxation and Philanthropy, OECD Tax Policy Studies, No. 27, Paris: OECD Publishing. $<$ https://doi.org/10.1787/df434a77-en>. 
Peloza, J. and Steel, P. (2005) 'The Price Elasticities of Charitable Contributions: A Meta-Analysis' Journal of Public Policy \& Marketing 24(2), p. 260.

Powell, A. et al. (2017) Australian Charities Report 2016, Sydney: Commonwealth of Australia.

Pozen, D. (2006) 'Remapping the Charitable Deduction' Connecticut Law Review 39(2), p. 531.

Reich, R. (2011) 'Toward a Political Theory of Philanthropy' in Illingworth, P., Pogge, T. and Wenar, L. (eds.), Giving Well: The Ethics of Philanthropy, Oxford: Oxford University Press, pp. 177-195.

Roodman, D. and Standley, S. (2006) Tax Policies to Promote Private Charitable Giving in DAC Countries, Center for Global Development Working Paper No. 82.

Sheppard, I., Fitzgerald, R. and Gonski, D. (2001) Report of the Inquiry into the Definition of Charities and Related Organisations, Canberra: Commonwealth of Australia.

Silver, N. and Buijze, R. (2020) 'Tax Incentives for Cross-Border Giving in an Era of Philanthropic Globalization: A Comparative Perspective' Canadian Journal of Comparative and Contemporary Law 6, p. 109.

Silver, N., McGregor-Lowndes, M. and Tarr, J. (2016) 'Should Tax Incentives for Charitable Giving Stop at Australia's Borders?' Sydney Law Review 38(1), p. 85.

Simon, J., Dale, H. and Chisolm, L. (2006) 'The Federal Tax Treatment of Charitable Organisations' in Powell, W. and Steinberg, R. (eds.), The Non Profit Sector: A Research Handbook, 2nd edn., New Haven: Yale University Press, p. 267.

Stewart, M. (2014) 'The Boundaries of Charities and Tax' in Harding, M., O'Connell, A. and Stewart, M. (eds.), Not-for-Profit Law: Theoretical and Comparative Perspectives, Cambridge: Cambridge University Press.

The Treasury (2015) Better Tax System, Better Australia, Tax Discussion Paper, Canberra: Commonwealth of Australia <http://bettertax.gov.au/publications/discussion-paper/>.

The Treasury (2018) Deductible Gift Recipient (DGR) Reforms: Consultation Paper, Canberra: Commonwealth of Australia < https://treasury.gov.au/consultation/c2018-t321162/>.

Wiepking, P. (2010) 'Democrats Support International Relief and the Upper Class Donates to Art? How Opportunity, Incentives and Confidence Affect Donations to Different Types of Charitable Organisations' Social Science Research 39(6), p. 1073.

Wood, T., Humphrey Cifuentes, A. and Pryke, J. (2014) Putting Our Money Where Our Mouths Are? Donations to NGOs and Support for ODA in Australia, Discussion Paper 37, Development Policy Centre, Australian National University.

\section{Cases}

Commissioners for Special Purposes of Income Tax v Pemsel [1891] AC 531

Federal Commissioner of Taxation v The Hunger Project Australia (2014) 221 FCR 302

Federal Commissioner of Taxation v Word Investments Ltd (2008) 236 CLR 204

\section{Legislation}

Australian Charities and Not-for-profits Commission Act 2012 (Cth)

Australian Charities and Not-for-profits Commission Amendment (2018 Measures No. 2) Regulations 2018 (Cth)

Charities Act 2013 (Cth)

Income Tax Assessment Act 1997 (Cth)

\section{Other legal authorities}

Australian Charities and Not-for-profits Commission (2016) Commissioner's Interpretation Statement: Public Benevolent Institutions, CIS 2016/03

Australian Taxation Office (2003) Taxation Ruling TR 2003/5, 'Income Tax and Fringe Benefits Tax: Public Benevolent Institutions'

Australian Taxation Office (2017) Taxation Ruling TR 2003/5W, 'Income Tax and Fringe Benefits Tax: Public Benevolent Institutions, Notice of Withdrawal' 
Australian Taxation Office (2018) Draft Taxation Ruling TR 2018/D1, 'The 'in Australia' Requirement for Certain Deductible Gift Recipients and Income Tax Exempt Entities'

Australian Taxation Office (2019) Taxation Ruling TR 2019/6, 'Income Tax: The 'in Australia' Requirement for Certain Deductible Gift Recipients and Income Tax Exempt Entities'

Explanatory Materials, Exposure Draft: Tax Laws Amendment (2014 Measures No \#) Bill 2014 (Cth)

Explanatory Memorandum, Tax Laws Amendment (Special Conditions for Not-for-profit Concessions) Bill 2012 (Cth) 